Robert Kurelić

\title{
RITUAL DEDITIO NA RELJEFU HRVATSKOGA VLADARA*
}

Robert Kurelić

Odsjek za povijest

Filozofski Fakultet u Puli

Pula

\author{
UDK 7.04(497.5)"10" \\ $94(497.5)^{\prime \prime} 10^{\prime \prime}:[316.47+316.48]$ \\ Prethodno priopćenje \\ Primljeno: 15.6.2016. \\ Prihvaćeno: 14.12.2016. \\ DOI: http://doi.org/10.21857/m3v76tz0wy
}

\begin{abstract}
Autor u prizoru na reljefu hrvatskoga vladara prepoznaje ranosrednjovjekovni ritual mirenja, dedicij (deditio). U radu se pojašnjava uloga i važnost simboličke komunikacije u političkom životu u ranome srednjem vijeku, postupak donošenja političkih odluka i važnost rituala mirenja za očuvanje stabilnosti poretka. Pojašnjava se uloga Henrika II. u mogućoj transmisiji prizora prema Monte Cassinu, a zatim i dalje prema Dalmaciji i to u skladu s promjenama koje je ovaj svetorimski vladar unio u shvaćanje carske vlasti, ali i u sam ritual deditio.
\end{abstract}

Ključne riječi: simbolička komunikacija, deditio, rituali mirenja, vladarska propaganda, ikonografija, Petar Krešimir IV., Dmitar Zvonimir

\section{Uvod}

Reljef vladara na prijestolju koji se danas nalazi na istočnoj ploči krsnog bazena krstionice sv. Ivana u Splitu već je stoljeće i pol predmet žustre rasprave u akademskim krugovima, ali i različitih, pa i dijametralno suprotnih tumačenja kako porijekla same ploče, tako i njezine ikonografije. Budući da recentni radovi na ovu temu sadrže i opsežne kritičke prikaze literature, osvrnut ću se ukratko samo na zaključke najrecentnijih istraživanja. Prvo pitanje koje se postavlja je o naravi središnjeg prikazanog lika koji okrunjen sjedi na prijestolju držeći u rukama križ i kuglu. Ivana Prijatelj-Pavičić drži da bi se moglo raditi o liku Krista ili kristološkoj simbolici, dok se Pavuša Vežić nastavlja na tezu uglednog beogradskog povjesničara umjetnosti

* Ovaj je rad sufinancirala Hrvatska zaklada za znanost projektom Izvori, pomagala $i$ studije za hrvatsku povijest od srednjeg vijeka do kraja dugog 19. stoljeća (HRZZ-IP-09-2014-6547). 
Svetozara Radojčića, a koju je zastupao i Ivo Petricioli, kako je riječ o kristološkoj simbolici, ali ne putem same osobe Spasitelja, već kao aluzija na njega kroz parabolu o okrutnom dužniku iz Matejeva evanđelja (Mt 18, 23-27). ${ }^{1}$ Većina autora se ipak priklanja tumačenju kako je riječ o svjetovnom vladaru, iako i tu postoji razilaženje o kojem bi točno kralju bila riječ. Tomislav Marasović smatra da je reljef naručio nadbiskup i metropolit Lovre Dalmatinac kao dio oltarne pregrade prigodom Zvonimirove krunidbe, pri čemu je ploča naknadno iskorištena za izgradnju krsnog zdenca. Prikazani lik je, dakako, identificirao kao kralja Zvonimira. ${ }^{2}$ Igor Fisković zastupa mišljenje da je riječ o Petru Krešimiru IV., a da se ploča izvorno nalazila u krunidbenoj crkvi sv. Petra i Mojsija u Solinu, poznatijoj i pod imenom Šuplja crkva. ${ }^{3}$ Vjerojatno najdalje u pokušaju identifikacije likova s reljefa otišao je Ivan Babić. On se priklanja mišljenju da je riječ o svjetovnom vladaru, Zvonimiru ili - manje vjerojatno Slavcu, dok u stajaćem liku prepoznaje Petra Črnjinu, a u polegnutome neku treću osobu (Strezu?) koja je izgubila spor od Črnjine pred kraljevim sudom. Time ujedno i izvornu lokaciju pluteja smješta u samostansku crkvu sv. Petra Gumajskog, otkud je u Split mogla biti donesena kao spolija, pri čemu je sjećanje na Petra i Zvonimira izbrisano micanjem natpisa koji ih je imenovao. ${ }^{4}$ Iako se većina autora slaže da je u ovome slučaju riječ o spoliji te da se plutej izvorno nalazio u nekom drugom kontekstu, Babićeva konstrukcija - iako zanimljiva - teško može naći potvrdu u dokazima. Značajnijim smatram njegov pokušaj identifikacije figura, pri čemu je osobita sljedeća tvrdnja: “Položaj i geste ležećeg lika - pruženih ruku s raširenim dlanovima ispod kraljeva prijestolja - ne upućuju toliko na padanje ničice u iskazivanju poštovanja i podložnosti koliko, čini nam se, u traženje milosti" ${ }^{5}$ Babić nadalje zaključuje da prizor prikazuje pravosudnu tematiku, odnosno da je ležeći lik izgubio nekakav spor u kojemu je odluku donio kralj u korist stajaćeg lika. U tome se dijelom preklapa s Fiskovićevim stavom kako na reljefu možemo prepoznati takozvanog rex iustitiae, odnosno "pravednog i milosrdnog zemaljskog vladara kojeg su vjernici iz sredine gdje se spomenik nalazio duboko štovali". ${ }^{6}$

U ovome radu pokušat ću ponuditi identifikaciju prizora na reljefu koja se dijelom naslanja na teze Ivana Babića i Igora Fiskovića, pri čemu smatram bitnim naglasiti tri premise. Prvo: priklanjam se mišljenju da je na reljefu prikazan svjetovni vladar, bez obzira na to je li riječ o Petru Krešimiru IV., Zvonimiru ili - a što je najmanje

1 Ivana Prijatelj-Pavičić, Prilog poznavanju reljefa na zdencu splitske krstionice, Zbornik Tomislava Marasovića, Split 2002., str. 348-350; Svetozar Radojčić, Ploča s likom vladara u krstionici splitske katedrale, Zbornik za likovne umetnosti, sv. 9, Novi Sad 1973., str. 3-13; Ivo Petricioli, Skulpture iz 11. st. u Zadru, Splitu i Solinu. Tragom srednjovjekovnih umjetnika, Zagreb 1983., str. 19, 23; Pavuša Vežić, Plutej s likom vladara iz krstionice u Splitu, Radovi Instituta za povijesi umjetnosti, sv. 24, Zagreb 2000., str. 7-16.

2 Tomislav Marasović, O krsnom bazenu splitske krstionice, Starohrvatska prosvjeta, ser. III, sv. 24, Split 1997., str. 7-56.

3 Igor Fisković, Reljef kralja Petra Krešimira IV., Split 2002., str. 253-340.

4 Ivo Babić, O reljefu s prikazom kralja iz splitske krstionice, Archaeologia Adriatica, sv. 4, Zadar 2010. str. 203-215.

5 Isto, str. 207.

6 Fisković, Reljef, str. 94. 
vjerojatno - Slavcu. Drugo: smatram da izvorna lokacija reljefa nije od presudne važnosti za pokušaj identifikacije prizora. Konačno, treće: slažem se s Fiskovićem da je vjerojatni ikonografski uzor za nastanak reljefa potekao s njemačkog dvora, a konkretno preko evanđelistara Henrika II. iz Monte Cassina. ${ }^{7}$ Mišljenja sam da scena prikazana na reljefu odgovara ritualu zvanom dedicij (deditio), najvažnijem mehanizmu mirenja unutar plemićke hijerarhije u ranome srednjem vijeku. Kako bih razjasnio razloge zbog kojih bi upravo dedicij mogao biti temom reljefa, potrebno je pojasniti ulogu rituala i simboličke komunikacije u društveno-političkom životu srednjega vijeka, način donošenja odluka u ranosrednjovjekovnim društvima, značaj dedicija u postupcima mirenja zavađenih strana te ulogu Henrika II. kao vjerojatnog uzora za ikonografski sadržaj reljefa.

\section{Rituali kao dio temelja srednjovjekovnog društveno-političkog uređenja}

U posljednjim desetljećima 20. stoljeća antropologija je imala izniman utjecaj na povijesnu znanost. Ponukani idejom da se na određena povijesna razdoblja, poput srednjega i ranoga novog vijeka, treba gledati očima kojima antropolozi sagledavaju strane zemlje ili izolirana plemena, povjesničari su prigrlili metode društvenih znanosti kako bi odgonetnuli svijet u kojemu je postojala velika isprepletenost politike i vjere. Došli su do zaključka kako su "religija i društvo integralno povezani, stoga proučavanje pojedinačnog djelovanja i običaja pruža uvid u vrijednosti, predodžbe i strukture čitavoga društva". ${ }^{8}$ Ritual je shvaćen kao čimbenik očuvanja stabilnosti društva i identiteta, a prema njemačkom povjesničaru Gerdu Althoffu, jednom od vodećih "povjesničara - antropologa", ritualnost i demonstrativnost tvorili su temelje političke komunikacije u srednjem vijeku. Althoff dalje konstatira kako je iznimno važno razlučiti rituale u srednjovjekovnoj javnoj komunikaciji od rituala koji se tiču prakticiranja vjere. ${ }^{9}$ Dok su akteri u religijskim ritualima bili neskloni inovacijama smatrajući da jedino slijepa predanost tradiciji naglašava Božju svemoć i vječnost, rituali u političkoj komunikaciji srednjega vijeka mogli su se mijenjati, osuvremenjivati ili čak ab ovo izmisliti kako bi odgovarali potrebama moćnika i vremena. Dok je kod prvih riječ o svojevrsnoj "sakralnoj ritualnoj rigidnosti", kod potonjih je naglašen "utilitarno-racionalni" princip. ${ }^{10} \mathrm{Na}$ ovakvom shvaćanju rituala su, uz Althoffa, izniman doprinos razumijevanju ranosrednjovjekovnog društva dali i brojni drugi poklonici antropološkog pristupa u historiografiji poput Patricka Gearya,

Isto, str. 124-128.

8 Alexandra Walsham, The Dangers of Ritual: Between Early Medieval Texts and Social Scientific Theory by Philipe Buc. Review Article, Past and Present, sv. 180, Oxford 2003., str. 277-287.

9 Zanimljivo je da je Catherine Bell u svojoj opsežnoj studiji o ritualima obradila vjerojatno sve postojeće teorije o ritualima osim onih koje se tiču medievistike: Catherine Bell, Ritual: Perspectives and Dimensions, Oxford 1997.

10 Gerd Althoff, The Variability of Rituals in the Middle Ages, u: Medieval Concepts of the Past: Ritual, Memory, Historiography, ur. Gerd Althoff - Johannes Fried - Patrick Geary, Cambridge 2002., str. 71-88. 
Robert Kurelić: Ritual deditio na reljefu hrvatskoga vladara

Zb. Odsjeka povij. znan. Zavoda povij. druš. znan. Hrvat. akad. znan. umjet., 34 (2016), str. 1-20

Karla Leysera, Janet Nelson, Mayke de Jong, Geoffreya Koziola, Davida A. Warnera i drugih. ${ }^{11}$ Geografski je tematika uglavnom bila omeđena područjem Franačkoga Carstva i država nasljednica, odnosno na Njemačku, Francusku i Italiju između 8. i 12. stoljeća, međutim u novije vrijeme na red su došle i druge regije poput Poljske ili Ugarske, ali i dalekoistočnih zemalja. ${ }^{12}$ Glasni kritičar primjene antropoloških metoda za izučavanje srednjovjekovnih društava svakako je francuski povjesničar Phillipe Buc. U svojoj izrazito polemičkoj knjizi The Dangers of Ritual, Buc je potpuno odbacio upotrebu pojma "ritual" koji smatra previše opterećenim značenjima i definicijama da bi u ičemu bio koristan za povijesnu znanost. Nadalje, tvrdi kako su njegovi prethodnici krenuli od pogrešne pretpostavke: "rituali" koje su identificirali u ranosrednjovjekovnim izvorima nisu odražavali stvarnost, već su im autori izvora svojom interpretacijom pridavali značenje. Drugim riječima, rituali nisu bili sredstvo političke komunikacije, već rezultat naknadne ideološke propagande. ${ }^{13}$ Oštre odgovore na njegovu knjigu objavili su Alexandra Walsham te od Buca prozvani Geoffrey Koziol koji naglašava da je izučavanje rituala u srednjovjekovnom kontekstu i dalje iznimno relevantna historiografska tema koja ne pokazuje znakove posustajanja, već nastavlja davati rezultate koji otkrivaju nove slojeve kompleksnih odnosa u srednjovjekovnim društvima ${ }^{14}$ Koziol je nedavno objavio i svoj magnum opus o "Politici sjećanja i identitetu u karolinškim kraljevskim ispravama", u kojem se nadovezuje na još jednu od Althoffovih osnovnih teza, o ključnoj ulozi performativnosti i insceniranja kako u svečanim, javnim događajima, tako i u svakodnevnim situacijama poput osobnih iskaza vjere. ${ }^{15}$ Karolinške diplomatičke izvore sagledava kao performativni

11 Gerd Althoff, Spielregeln der Politik, Darmstadt 1997.; isti, Die Macht der Rituale: Symbolik und Herrschaft im Mittelalter, Darmstadt 2003.; Patrick Geary, Vivre en conflit dans une France sans état: typologie des mécanismes de réglement des conflits (1050-1200), Annales, E.S.C., sv. 41, Paris 1986., str. 1107-1133; Karl Leyser, Ritual, Ceremony and Gesture: Ottonian Germany, u: Communications and Power: the Carolingian and Ottonian Centuries, ur. Timothy Reuter, London 1994., str. 189-213; Janet Nelson, Politics and Ritual in Early Medieval Europe, London 1986.; Mayke de Jong, Adding Instult to Injury: Julian of Toledo and his Historia Wambae, u: The Visigoths from the Migration Period to the Seventh Century: An Ethnographic Perspective, ur. Peter Heather, Woodbridge 1999., str. 373-389; Geoffrey Koziol, Begging Pardon and Favor: Ritual and Political Order in Early Medieval France, Ithaca 1992.; David A. Warner, Ritual and Memory in the Ottonian Reich: The Ceremony of Adventus, Speculum, god. 76, br. 2, Cambridge, Massachusetts 2001., str. 255-283.

12 Zbigniew Dalewski, Ritual and Politics: Writing the History of a Dynastic Conflict in Medieval Poland, Leiden 2008.; Dušan Zupka, Ritual and Symbolic Communication in Medieval Hungary under the Árpád Dynasty, Leiden 2016.; Medieval and Early Modern Rituals: Formalized Behavior in Europe, China and Japan, ur. Joëlle Rollo-Koster, Leiden 2002.

13 Phillipe Buc, The Danger of Ritual: Between Early Medieval Texts and Social Scientific Theory, Princeton 2001.

14 Walsham, The Dangers, passim; Geoffrey Koziol, The Dangers of Polemic: Is Ritual still an Interesting Topic of Historical Study, Early Medieval Europe, sv. 4, Hoboken, New Jersey 2002., str. 367-388. Koziol je posebno izdvojio dva iznimna rada koji se bave ranosrednjovjekovnim temama: Ritual before the Altar Marguerite Ragnow, te Burchard of Worms and Female Magical Ritual Marthe Ramptom iz zbornika Medieval and Early Modern Rituals (vidi bilj. 12). Dok oba smatra izvanrednima, rad Marguerite Rangow naziva "one of the best articles I have ever read on any medieval ritual".

15 Gerd Althoff, Inszenierung verpflichtet: zum Verständnis ritueller Akte bei Papst-Kaiser-Begegnungen im 12. Jahrhundert, Frühmittelalterliche Studien, sv. 35, Berlin 2001., str. 61-84. Naglašava i kako se 
Robert Kurelić: Ritual deditio na reljefu hrvatskoga vladara

Zb. Odsjeka povij. znan. Zavoda povij. druš. znan. Hrvat. akad. znan. umjet., 34 (2016), str. 1-20

čin sui iuris umjesto kao dodatak korišten unutar određenog insceniranog rituala. Time je otišao korak dalje od dotadašnje historiografije te naznačio nove pravce u istraživanjima rituala, locirajući i identificirajući ih i ondje gdje njegovi prethodnici nisu gledali. ${ }^{16}$ Iz spomenute historiografije jasno je da je proučavanje rituala u srednjovjekovnom kontekstu još uvijek vrlo dinamično i neiscrpljeno područje istraživanja koje još mnogo toga može reći o načinu funkcioniranja srednjovjekovnih društava.

Rituali i simbolička komunikacija u ranome srednjem vijeku imali su vrlo važnu ulogu u stvaranju i održavanju vladajuće hijerarhije ili, suvremenim rječnikom rečeno, državnog poretka. Rituali prijelaza, odnosno rites of passage, poput rođenja, krštenja, vjenčanja, smrti i drugih odavno su priznati u antropologiji i etnologiji kao važan dio ljudskog života u tome što najavljuju i ostvaruju tranziciju iz jednog društvenog statusa u drugi. Ulazak u kršćansku zajednicu, punoljetnost i iskorak u svijet odraslih ili očinstvo samo su neki od mnogobrojnih događaja koje simbolički obilježavamo putem raznih ceremonija i rituala kako bi im dali svečani karakter i snagu. ${ }^{17}$ Pritom su takvi simbolički iskazi redovito javni, inscenirani i propisani, bilo formalnim ili neformalnim pravilima koje članovi zajednice mogu bez većih problema prepoznati i razumjeti. Srednjovjekovna država bila je shvaćana kao uvećana preslika velikaškog domaćinstva, dok su visoke dvorske službe poput maršala, peharnika ili trpezara, a čiji su nositelji bili članovi najvišeg plemstva, trebale evocirati predodžbu o kraljevom dvoru kao virtualnom domaćinstvu čitave države. "Časne službe" (njem. Erzamt) formalno je odredio Karlo IV. u Zlatnoj buli 1356., povezavši ih s elektorima Svetog Rimskog Carstva, međutim njihovo se podrijetlo u izvorima može pratiti još od krunidbe Otona I. Widukind iz Corveya zapisao je kako su kralja tijekom krunidbenih svečanosti služili njemački vojvode i to tako da je Gizelbert Lotarinški pripremio proslavu, Eberhard Švapski objed, Herman Franački piće, a Arnulf Bavarski pobrinuo se za vitezove i logor. Sličan opis dao je i Thietmar Merseburški za krunidbu Otona III. ${ }^{18} \mathrm{U}$ spomenutim je situacijama istovremeno odaslano više poruka: naglašeno je zajedništvo vladara i njegovih velikaša kao članova virtualnog domaćinstva, odnosno Carstva, implicirana je hijerarhija na čijem je čelu neosporni vladar, te javno odaslana poruka o transferu moći na novoga cara, što predstavlja - kako je ustvrdio i Jacques Le Goff na primjeru francuskog krunidbenog ceremonijala u vrijeme Luja IX. - ritual prijelaza, ali na kvalitativno višoj razini od već

često pogrešno precjenjuje spontanost $u$ religijskom izričaju, pripisujući ljudima znatno veći stupanj pobožnosti od onoga koji su stvarno imali, umjesto da se sagleda u kontekstu opće usmjerenosti na teatralnost, insceniranost i performativnost u tadašnjoj komunikaciji. Usp. Althoff, Spielregeln der Politik, str. 248.

16 Geoffrey Koziol, The Politics of Memory and Identity in Carolingian Royal Diplomas: The West Frankish Kingdom (840-987), Turnhout 2012., str. 3.

17 Edmund Leach, Culture and Communication, Cambridge 1976., str. 77-79; Victor Turner, The Ritual Process: Structure and Anti-Structure, Harmondsworth 1969., str. 98-99.

18 Franz-Reiner Erkens, Kurfürsten und Königswahl. Zu neuen Theorien über den Königswahlparagraphen im Sachsenspiegel und die Entstehung des Kurfürstenkollegiums, Hannover 2002., str. 87; Hugo Haedicke, Kurrecht und Erzamt der Laienfürsten, Nürnberg 1872., str. 66. 
Robert Kurelić: Ritual deditio na reljefu hrvatskoga vladara

Zb. Odsjeka povij. znan. Zavoda povij. druš. znan. Hrvat. akad. znan. umjet., 34 (2016), str. 1-20

spomenutih koji se odnose na privatni život pojedinaca. ${ }^{19}$ Takvi "državni rituali prijelaza" mogu se, pored krunidbe, prepoznati i u "radosnom ulasku" vladara u prijestolnicu, rođenju prestolonasljednika, stjecanju viteštva, kraljevskom pogrebu i drugim ceremonijama koje su bile od iznimne simboličke važnosti za propagiranje i potvrđivanje vlasti vladara i hijerarhije kojoj je stajao na čelu. ${ }^{20}$

Navedeni rituali prijelaza bili su karakteristični za razdoblja relativnog mira, iako se i sam pojam mira treba uzeti s rezervom s obzirom na to da su u ranom i razvijenom srednjem vijeku fajde (od njem. Fehde) među plemstvom bile gotovo redovita pojava. ${ }^{21}$ Društva koja su se zasnivala na držanju zemlje bila su inherentno konfliktna jer je količina zemlje koja je stajala na raspolaganju bila ograničena, a uspon ambicioznih pojedinaca bio je moguć jedino na štetu drugih, bilo da je riječ o dobrovoljnom ili prisilnom prijenosu posjedovnih prava. Čak su i miroljubivi zemljoposjednici morali biti spremni na obranu svojih prava, pred sudom ili silom. ${ }^{22}$ I sam vladar bio je dijelom te iste piramide i morao se brinuti za svoje krunske posjede kao i svaki drugi zemljoposjednik te je, posljedično, mogao biti i sam uvučen u političke i oružane sukobe..$^{23}$ Inauguracije i druge državne svečanosti koje su, kako bi imale težinu i ispunile svoju svrhu, trebale publiku i svjedoke, svakako su se teško mogle provoditi ako su velikaši ili vladar bili aktivno uključeni u fajde koje bi im odvraćale pozornost ili ih na dulje vrijeme udaljile od dvora. Problem stalnih sukoba se, međutim, kosio s uređenom vizijom srednjovjekovne države kakva je postojala u suvremenoj historiografskoj tradiciji. Njemačka historiografija 19. i 20. stoljeća bila je mišlje-

19 Jacques Le Goff, A Coronation Program for the Age of Saint Louis: The Ordo of 1250, u: Coronations, ur. János M. Bak, Berkley - Oxford 1990., str. 46-56.

20 Pored već citiranih djela vidi i: Court Ceremonies and Rituals of Power in Byzantium and the Medieval Mediterranean, ur. Alexander Beihammer - Stavroula Constantinou - Maria Parani, Leiden 2013.; David Cannadine, Rituals of Royalty: Power and Ceremonial in Traditional Societies, Cambridge 1992.; Nicola McDonald - W. M. Ormond, Rites of Passage: Cultures of Transition in the Fourteenth Century, Woodbridge 2004.; Segio Bertelli, The King's Body Sacred Rituals of Power in Medieval and Early Modern Europe, University Park, Pennsylvania 2001.; Gordon Kipling, Enter the King: Theatre, Liturgy, and Ritual in the Medieval Civic Triumph, Oxford 1998.

21 Većina postojećih kapitalnih djela o fajdama odnose se na razdoblje kasnoga srednjeg vijeka, međutim fajde su bile u velikoj mjeri prisutne i u ranome srednjem vijeku. Vidi: J. M. Wallace-Hadrill, The bloodfeud of the Franks, u: isti, The Long-Haired Kings, London 1962., str. 121-147; Violence and Society in the Early Medieval West: Private, Public and Ritual Violence in Early Medieval Society, ur. Guy Halsall, Woodbridge 2002.

22 Andrew M. Spencer, Nobility and Kingship in Medieval England: The Earls and Edward (1272-1307), Cambridge 2014., str. 103-104.

23 Vladari se nisu, koliko je meni poznato, sukobljavali sa svojim velikašima oko relativno trivijalnih razloga kao što su granična pitanja, pašnjaci ili pojilišta, ali su se znali uključiti u nasljedne sporove polazeći od stajališta da je sva zemlja u kraljevstvu u osnovi njihova. Na taj bi način ulazili u fajde s nezadovoljnim velikašima ako bi osporavali ili mijenjali dogovorene nasljedne sporazume. Primjerice, Henrik III. bio je u dugogodišnjem sporu s Gotfridom III. Lotarinškim kojemu nije priznavao pravo na nasljedstvo svoga brata Gocela. Henrik je htio spriječiti da obje Lotaringije dođu pod vlast jedne osobe zbog njihova osjetljiva položaja na granici s Francuskom, te je oduzimanje Donje Lotaringije tumačio kao svoje pravo nasljedstva nakon Gocelove smrti bez neposrednog nasljednika. Gotfrid je, međutim, situaciju doživio kao zlouporabu kraljevskih ovlasti i otimačinu te je reagirao kao što bi i niži velikaši u graničnom sporovima. Vidi: Egon Boshof, Lothringen, Frankreich und das Reich in der Regierungszeit Heinrichs III, Rheinische Vierteljahrsblätter, sv. 42, Bonn 1978., str. 63-127. 
nja da je kraljevska vlast u ranom srednjem vijeku, u takozvano "zlatno doba" carske velevlasti (Reichsherrlichkeit) bila izrazito moćna, ako ne i apsolutna. U predodžbi romantičarskih povjesničara suočenih s realnošću rascjepkanosti Svetog Rimskog Carstva u novom vijeku, te Rajnske konfederacije koja ga je naslijedila nakon 1806. davna su se vremena mitologizirala gotovo do apsurda, a Otonu I. i Fridriku Barbarossi pripisivale su se ovlasti i autoritet gotovo nalik onima koje podrazumijevamo za orijentalne despocije. To je bilo sasvim u skladu s nacionalističkim viđenjem svijeta i željom da se u dalekoj prošlosti locira trenutak u kojemu je postojala idealna država prije nego li se počela postupno mrviti uzurpacijom niza prava od strane velikaša, što je tijekom stoljeća postupno nagrizalo središnju vlast dok je nije gotovo u potpunosti upropastilo. ${ }^{24}$ Obol ovakvom tumačenju dala je i propaganda oko dinastije Hohenzollern koju se, pogotovo nakon ujedinjenja Njemačke 1871., pokušavalo uklopiti u tradicije srednjovjekovnog kraljevstva na način da se suvremeno i birokratizirano Njemačko Carstvo prikaže kao povratak na "dobra stara vremena" dinastije Štaufovaca. ${ }^{25}$ Ova fascinacija trajala je do kraja razdoblja nacističke vlasti za trajanja koje je 1936. objavljen reprint knjige o Fridriku II., iako joj je autor bio Židov Ernst H. Kantorowicz. ${ }^{26}$

\section{Consilium - mehanizam odlučivanja}

Srednjovjekovna politika je, međutim, u svojoj naravi bila izrazito personalna te je pristup "uhu vladara", odnosno njegova naklonost koja je omogućavala iznošenje vlastitog mišljenja i utjecaj na donošenja odluka, bio od iznimne važnosti za uspješnost pojedinog plemića u javno-političkom životu i probitak njegove dinastije. Proces odlučivanja nije se zasnivao isključivo na osobi vladara koji s visoka uređuje odnose u svojoj državi. Naprotiv, vlast je bila konsenzualnog karaktera, a vladareva moć ovisila je o njegovoj sposobnosti da svoju volju nametne krupnim velikašima koji su često tvorili i njegov najuži krug savjetnika. Taj proces što ga je Althoff nazvao "izgradnjom volje" (Willensbildung) zasnivao se prvenstveno na sposobnosti nagovaranja, karizmi i autoritetu, a ne na formalnoj zapovjednoj ovlasti vladara ${ }^{27}$ Pritom je važno napomenuti da su velikaši kraljevstva i, o njima ovisni ljudi niže u hijerarhiji, ujedno tvorili i svojevrsni birokratski aparat srednjovjekovne

24 Christian Simon, Historiographie: Eine Einführung, Stuttgart 1996., str. 117; Peter Moraw, Herrschaft, u: Geschichtliche Grundbegriffe. Historisches Lexikon zur politisch-sozialen Sprache in Deutschland, sv. 3, ur. Otto Brunner - Werner Conze - Reinhart Koselleck, Stuttgart 1982., str. 1-102; Camilla G. Kaul Friedrich Barbarossa im Kyffhäuser: Bilder eines nationalen Mythos im 19. Jahrhundert, Köln 2007., str. 757.

25 Cristiane Sutter, Die Kreuzfahrerrezeption in der deutschen Malerei des 19. Jahrhunderts, Münster 2011., str. 143, 225-231.

26 Ernst H. Kantorowicz, Friedrich der Zweite, Berlin 1936. Sam je Kantorowicz nakon rata upozorio na opasnost da se plodovi istraživačkog rada mogu zloupotrijebiti od strane totalitarnih režima. O tome i odnosu njemačke historiografije prema Kantorowiczu, vidi: Johannes Fried, Ernst H. Kantorowicz and postwar Historiography: German and European Perspectives, u: Ernst Kantorowicz: Erträge der Doppeltagung, ur. Robert Benson - Johannes Fried, Stuttgart 1997., str. 180-201.

27 Gerd Althoff, Family, Friends and Followers: Political and Social Bonds in Early Medieval Europe, Cambridge 2004., str. 10-16. 
Robert Kurelić: Ritual deditio na reljefu hrvatskoga vladara

Zb. Odsjeka povij. znan. Zavoda povij. druš. znan. Hrvat. akad. znan. umjet., 34 (2016), str. 1-20

države, odnosno o njihovoj dobroj volji i susretljivosti ovisila je provedba odluka središnje vlasti na terenu. ${ }^{28}$ Takav postupak koji se nazivao consilium ili savjet odvijao se prema točno propisanim pravilima, a spominje se još i u karolinškim kapitularima. ${ }^{29}$ Vladar je samostalno sazivao vijeće, odlučivao o njegovom dnevnom redu i, u konačnici, donosio odluku: međutim, u praksi je ona ovisila o rasporedu snaga među okupljenim velikašima. Srednjovjekovno društvo počivalo je na časti koja je bila krhka i lako se je mogla povrijediti, a sudionici političkog života su, prema riječima američkog povjesničara Williama Iana Millera, imali "istančan osjećaj za to zavide li im drugi više nego li oni sami zavide njima", stoga su razgovori vođeni na način kako bi se drugoj strani, ako je to bilo ikako moguće, ostavila mogućnost uzmaka i čuvanja obraza. ${ }^{30}$ Javni izljevi bijesa su se izbjegavali osim ako i sami nisu bili dio dogovorenog "scenarija". ${ }^{31}$ Mišljenja drugih sudionika političkog procesa ispitivala su se za objedima, u povjerljivim razgovorima ili preko posrednika. Takvo postupanje odugovlačilo je čitav proces, pa su veći sastanci mogli trajati tjednima, mjesecima ili dulje jer je odugovlačenje bilo poželjnije rješenje od konačnog zatvaranja vrata suparniku. Pritom su obje strane, u povjerljivim susretima i razgovorima (colloquium secretum ili colloquium inter familiares), ispitivali razmišljanja neutralnih u političkom procesu, odnosno onih velikaša koji nisu pripadali nijednoj frakciji ili se nisu opredijelili o određenom pitanje, te su pokušavali izgraditi većinu za svoj politički program. Dugotrajan i oprezan proces bio je neminovan u društvima koja su se sastojala od niza interesnih grupacija isprepletenih mrežom savezništva i rodbinskih odnosa. Ovakve horizontalne veze između međusobno jednakih članova društva, primjerice među kneževima i ostalim neposrednim krunskim vazalima, ponekad su bile važnije od vertikalnih spona ovisnosti između seniora i vazala. ${ }^{32}$ Ranosrednjovjekovno ritualno prijateljstvo ili amicitia služilo je za sklapanje savezništva među plemstvom, a Henrik I. nudio je svojim poraženim vazalima "prijateljstvo" umjesto poniženja kako bi formalno vertikalnim sponama dao simbolički privid horizontalnosti i time

28 Engleska je bila donekle drugačija zbog specifične uloge šerifa kao predstavnika kraljevske vlasti u grofovijama, ali i nepostojanja velikih i zaokruženih teritorijalnih gospodstava koja bi davala snagu krupnim velikašima protiv kralja što se počelo mijenjati potkraj 14. stoljeća kada dolazi do pojave koju engleska historiografija naziva "bastard feudalism". Vidi: Spencer, Nobility and Kingship, str. 114. Nadalje, znakovito je da se, za razliku od Engleske i Francuske u kojima su se formirala profesionalna vijeća koja su savjetovala vladare, u Njemačkoj čitav srednji vijek zadržao neposredan i velik utjecaj velikaša na djelovanje vlasti. Althoff, Family, Friends and Followers, str. 11, bilj. 29.

29 Osim toga, u takozvanim "Ogledalima prinčeva" koja su sadržavala upute i pravila ponašanja za sinove vladara i velikaša, često se i izričito zahtjeva da se vladar okruži dobrim i odstrani loše savjetnike. Rachel Stone, Morality and Masculinity in the Carolingian Empire, Cambridge 2012., str. 142-148.

30 William Ian Miller, The Anatomy of Disgust, Cambridge, Massachusetts 1997., str. 144.

31 Vidi niz radova na temu performative upotrebe bijesa u komunikaciji, u: Anger's Past: The Social Uses of an Emotion in the Middle Ages, Ithaca, New York 1998.

32 Susan Reynolds je u svome radu ukazala na ovaj izuzetno dinamičan i važan aspekt za razumijevanje političkih i društvenih odnosa u srednjem vijeku: Kingdoms and Communities in Western Europe (9001300), Oxford 1984. 
umanjio poniženje protivnika. ${ }^{33}$ Time je, ujedno, i njihov odnos predstavio kao "kooperativan umjesto hijerarhijskog". ${ }^{34}$ Konačna odluka je uvijek, formalno-pravno, pripadala vladaru koji bi je, u pravilu donio tek nakon što bi utvrdio stavove moćnika o predmetu rasprave. Fridrik Barbarossa godinama je ignorirao pritužbe protiv vojvode Henrika Lava, a na dnevni red ih je stavio tek u onom trenutku kad ga je odlučio lišiti njegovih vojvodstava. ${ }^{35}$ Ukoliko bi vladar donio odluku kojoj se protivi većina moćnika u kraljevstvu, riskirao je mogućnost i otvorene bune protiv svoje vlasti, gubitka autoriteta i prestiža, što je moglo rezultirati i svrgavanjem s prijestolja. ${ }^{36}$ Ivan bez Zemlje je, primjerice, smatran tiraninom jer je odluke donosio bez prethodno postignutog konsenzusa sa svojim barunima o čemu svjedoči i sadržaj Magne Carte. ${ }^{37}$ Problematiku je najbolje sažela Verena Epp: “Budući da je u osnovi treba promatrati kao nastavak skupa društvenih odnosa obilježenih profanim antičkim te kršćanskim predodžbama, a sve pod pojmom amicitia, ranosrednjovjekovna vlast (Herrschaft) bila je interaktivni, dijaloški i prema konsenzusu usmjereni proces, a nikako jednosmjerni pravac zapovjedi i poslušnosti kako nam sugerira upotreba pojma pod utjecajem devetnaestostoljetne hegelijanske predodžbe o državi" ${ }^{38}$

\section{Dedicij - ritual podčinjenja i mirenja između vladara i velikaša}

Za sudjelovanje na consiliumu, što je povlačilo i utjecaj na državnu politiku, pristup informacijama, te privilegije koje su proizlazile iz kraljeve bliskosti i milosti, potreban je bio, prema Althoffovim riječima "neprekinuti odnos s kraljem". ${ }^{99}$ To je značilo da je bilo kakav sukob između vladara i velikaša narušavao temelje hijerarhije i stabilnost društva budući da je s jedne strane isključivao zavađenog vazala iz politike, a s druge je vladara lišavao dijela njegovog operativnog kadra jer je vazal sa sobom u pravilu odvodio i čitavu svoju vertikalnu mrežu, a vjerojatno i dio horizontalne ako bi ga podržali saveznici i rođaci. ${ }^{40}$ Obje strane dijelile su interes da se

33 Gerd Althoff, Amicitiae und pacta. Bündnis, Einigung, Politik und Gebetsdenken im beginnenden 10. Jahrhundert, Hanover 1992., str. 88-96; Gerd Althoff - Hagen Keller, Heinrich I. und Otto der Grosse: Neubeginn auf karolingischem Erbe, Göttingen, Zürich 1985., str. 112-133.

34 Bernhard Jussen, Introduction, u: Ordering Medieval Societies: Perspectives on Intellectual and Practical modes of shaping social relations, ur. Bernhard Jussen, Philadephia 2001., str. 1-14.

35 Althoff, Spielregln der Politik, str. 157-183; isti, Die Macht der Rituale, str. 16-18.

36 Ingmar Krause, Konflikt und Ritual im Herrschaftsbereich der frühen Capetinger: Untersuchungen zur Darstellung und Funktion symbolischen Verhaltens, Münster 2006., str. 87-94.

37 "In the barons' opinion, he should take counsel with great men of distinguished lineage, suitable spokesmen for the kingdom as a whole" (Ralph V. Turner, Magna Carta; Through the Ages, Harlow 2003. str. 73-76).

38 Verena Epp, Zur Geschichte personaler, sozialer, politischer und geistlicher Beziehungen im frühen Mittelalter, Stuttgart 1999., str. 307. Epp koncept amicitiae shvaća i kao savez koji nudi potvrdu statusa unutar grupe te zaštitu prema van od neprijatelja i protiv ugroze vlastitoga položaja u hijerarhiji, a sve to uz blagoslov i garanciju Boga. Sam savez je, dakle, imao i religioznu dimenziju.

39 Althoff, Die Macht der Rituale, str. 17.

40 Zanimljiv je primjer vojvode Ernesta Švapskog koji se pobunio protiv Konrada II. Car mu je na skupu u Ingelheimu 1030., u znak iskupljenja, naredio da se pridruži carskoj vojsci u pohodu protiv 
nesporazumi riješe i ponovno uspostavi status quo ante jer su dugotrajne fajde otvarale mogućnost daljnjoj eskalaciji s nesagledivim posljedicama. Uključivanje drugih velikaša moglo je narušiti vladarev autoritet, pa i ugroziti samo prijestolje. Sukob Henrika IV. s papom Grgurom VII., iako kvalitativno drugačiji od klasičnih fajdi budući da je jedna od sukobljenih strana bila papinstvo, rezultirao je izborom protukralja Rudolfa Švapskog, međutim papinsko izopćenje bilo je samo povod odluci kneževa o Henrikovom svrgavanju. Uzrok je ležao u višegodišnjem sukobu kneževa i kralja oko njegova pokušaja izgradnje dinastičke moći u Saskoj, čemu su se oni otvoreno suprotstavljali, a njihove je opetovane simboličke i javne poruke on sustavno ignorirao. ${ }^{41}$ Kako bi se prekinuli sukobi i smirile tenzije unutar hijerarhije korišten je poseban antički ritual prilagođen srednjovjekovnim potrebama - dedicij (deditio).

Temelji dedicija postavljeni su još u merovinško doba. Njime je "izopćenik" mogao ponovno steći vladarevu milost i reintegrirati se u društvo, a politički sustav koji nije trpio "odmetnutost" od "feudalne piramide" na taj se način liječio. ${ }^{42}$ Dok je u merovinško vrijeme mehanizam mirenja s vladarom još uvijek imao određene nedostatke koji su otežavali njegovu punu primjenu - $u$ ta je vremena još izostao princip obveznosti koji bi molitelju za milost garantirao da će istu i ostvariti te se činom podvrgavanja sigurno vratiti na svoje mjesto u hijerarhiji - od karolinškog je doba isti već u potpunosti zaživio, a vrhunac dosegao u 10. stoljeću u vrijeme otonske dinastije. ${ }^{43}$ Pritom treba napomenuti da je dedicij zaživio u Istočnoj Franačkoj, odnosno u Njemačkoj, dok je na Zapadu bio znatno rjeđi. ${ }^{44}$

Dedicij nije bio čisti ritual mirenja među jednakima poput, primjerice "poljupca mira" koji je u svojim istraživanjima obradio Kiril Petkov. ${ }^{45}$ Budući da je u fajdama između vladara i podanika postojala razlika u položaju, redovito je jedna strana, u pravilu velikaši koji su se sukobljavali s kraljem, morala popustiti, makar prividno, te kleknuti ili pasti ničice kako bi se sukob razriješio. Time je jasno naglašeno da u ritualu, barem simbolički, postoje dominantna i inferiorna strana. Srednjovjekovni je model ime i načelni oblik preuzeo iz rimske institucije uspostave vrhovništva nad narodima bez primjene sile, ali uz učinak nalik osvajanju. Sam pojam značio je

svoga vazala i prijatelja Wernera Kyburškog, čemu se Ernest suprotstavio, zbog čega je proglašen hostis publicus imperatoris, i lišen vojvodstva. Zbog svoje vjernosti vazalu i prijatelju u nekrologu samostana u Sv. Gallenu proglašen je "Ponosom Alemana" (decus Alamanorum), te je postao i omiljenom književnom temom. Vidi: Hansmartin Schwarzmaier, Hadwig und Ernst II. Schwäbische Herzogsbilder zwischen Geschichtsforschung, Legende und Dichtung, Frühmittelalterliche Studien, sv. 36, Bonn 2002., str. 285-315.

41 Lutz Fenske, Adelsopposition und kirchliche Reformbewegung im östlichen Sachsen. Entstehung und Wirkung des sächsischen Widerstandes gegen das salische Königtum während des Investiturstreites, Göttingen 1977.

42 Naglašavam da pojam "feudalan" koristim isključivo kao asocijaciju, uvažavajući opsežnu literaturu koja je upotrebu pojma stavila pod znak pitanja. Susan Reynolds, Fiefs and Vassals: The Medieval Evidence Reinterpreted, New York - Oxford 1994.

43 Althoff, Spielregeln der Politik, str. 99-125; isti, Die Macht der Rituale, str. 32-130.

44 Usp. Koziol, Begging Pardon, str. 185.

45 Kiril Petkov, The Kiss of Peace: Ritual, Self, and Society in the High and Late Medieval West, Leiden 2003. 
"predaju". Rimski dedicij spadao je u domenu pravnog posla, stoga se odvijao prema strogo određenim pravilima i religijski određenim formulama, poput kupoprodaje ili manumisije. Vršen je pod prijetnjom sile, ali i uz nešto lakše posljedice po pokorene narode od vojnog osvajanja. Iako je pokoreni narod koji se bio ostavljen na milost i nemilost Rimljana - Scipion Emilije prodao je, primjerice, Numantince kao roblje i uništio njihov grad nakon dedicija - njegova svrha bila je da "čvrsto potvrdi superiorni status i dignitet Rima: zastraši neprijatelja, a zatim da, kad je pleme pošteđeno, generira zahvalnost" ${ }^{46}$

Upravo je međuodnos između bezuvjetne predaje i zahvalnosti za stečenu milost tvorio jezgru srednjovjekovnog dedicija uz jednu bitnu iznimku. Dedicij je u međuvremenu iz pravne prešao u simboličku sferu, a pridodana mu je i snažna religijska nadgradnja. "Kralj je kao vicarius Christi primao pokajničkog pobunjenika. I to je bilo stoljeće par excellence, $\mathrm{u}$ kojemu su sacerdotium i regnum zamijenili svoje prerogative". ${ }^{47}$ Time je vladar mogao nastupiti kristomimetično i tako, primajući poniznog pobunjenika kao sina razmetnoga, naglasiti svoju vlast temeljenu na milosti Božjoj. Dok je dedicij izvana naizgled odražavao smisao i pravila svog rimskog uzora, u jednomu ipak bitno razlikovao. U rimsko vrijeme suparnici Rima bili suočeni s izborom: podčiniti se ili se izložiti vojnoj pogibelji. Pritom je opcija predaje bila dostupna samo dok opsadne sprave ne dotaknu zidine grada, a morala je biti bezuvjetna. Kao što pokazuje primjer Numantinaca, nije postojala nikakva garancija da će milost biti pružena doli želje rimskih generala da blaži tretman posluži kao motivacija budućim protivnicima za pristanak na dedicij koji je veličao ne samo snagu Rima, već i vojskovođe koji bi ga uspio ostvariti. Srednjovjekovni dedicij je, međutim, naglasak stavio isključivo na formu, zanemarivši sadržaj tako da je pravna pozadina u potpunosti izostala dok je sva pažnja usmjerena na ritual podčinjenja koji postaje samom sebi svrha. U svijesti barbarskih naroda koji su imali prilike nazočiti rimskim ritualima i ceremonijama vjerojatno je samo vanjština ostajala upamćena kao bitni element samog događaja, dok je kompleksni pravni sadržaj u vizualnoj i nepismenoj kulturi ranoga srednjega vijeka postupno gubio na značenju zajedno s rimskim pravom na kojemu se temeljio. Dedicij je na političkoj sceni srednjovjekovnog društva svoj učinak generirao samim izvršenjem rituala, odnosno, čin padanja ničice pred vladarem ili suparnikom u političkom sukobu te stjecanje milosti i oprosta nisu bili sredstvo, već cilj za sudionike. Nadmoćni je akter u sporu svoju zadovoljštinu

46 Susan P. Mattern, Rome and the Enemy: Imperial Strategy in the Principate, Berkeley 1999., str. 217-219. Unatoč pokušajima da se i u rimsko vrijeme prepozna mogućnost "uvjetne" ili dogovorene predaje, takva nije postojala, već je ovisila isključivo o dobroj volji rimskih vojskovođa ili političara budući da je zajednica koja se predala putem dedicija izgubila svoj suverenitet i, kao takva, više nije mogla sklapati nikakve dogovore i sporazume prema načelima rimskog prava, pa ni zahtijevati milost. Vidi Arthur Eckstein, Glabrio and the Aetolians: A Note on Deditio, Transactions of the American Philological Society, sv. 125, Philadelphia 1995., str. 271-289.

47 Timothy Reuter, Contextualizing Canossa: excommunication, penance, surrender, reconciliation, u: isti, Medieval Polities and Modern Mentalities, ur. Janet Nelson, Cambridge 2006., str. 147-166, ovdje, str. 162. 
stjecao, naizgled spontanim, performativnim aktom podčinjenoga koji je svim okupljenim svjedocima - dedicij je uvijek bio razglašen i javan događaj - odašiljao jasnu poruku o položaju svih sudionika u hijerarhiji, dok je slabiji zauzvrat stjecao milost i javno obećanu zaštitu od daljnjih vojnih ili drugih djelovanja protiv njegovih interesa. Treba, naime, imati u vidu da je dediciju uglavnom prethodio politički i vojni pritisak, bilo stvaran ili impliciran. U okvirima tadašnjeg shvaćanja časti i čuvanja obraza, vođeni su pregovori posredstvom neutralne treće strane, uglednih velikaša, zajedničkih rođaka ili visokih crkvenih dužnosnika čiji je zadatak bio utanačiti uvjete dedicija prihvatljive za obje strane. Pritom je, u pravilu, cilj vladara bio javna demonstracija poniznosti od strane odmetnutog podanika, dok je druga, slabija, strana bila zainteresirana da prođe sa što manjim teritorijalnim i materijalnim gubicima.

Problematikom rješavanja sukoba $\mathrm{u}$ srednjovjekovnom društvu bavili su se brojni autori, među kojima se posebno mogu istaknuti William Ian Miller, Patrick Geary, Kiril Petkov, Walter Pohl i Gerd Althoff. ${ }^{48}$ Potonji je u svom znanstvenom opusu najveću pažnju posvetio upravo dediciju za koji navodi da se sastojao od četiri koraka odnosno pravila: "1. činjenica, provedba i ishod su prethodno utvrđeni pregovorima; 2 . provedba se odvija u prisustvu javnosti; 3 . tražitelj milosti pada ničice povezan sa samokritikom i 4 . oprost" ${ }^{49}$ Prva tri koraka prvi su put zabilježena još u vrijeme fajde Karla Velikog s vojvodom Tasilonom koji je, pod prijetnjom vojne intervencije i ostavljen od svojih ljudi, morao izručiti svoje vojvodstvo da bi kasnije, na sinodu u Frankfurtu 794., na ponizan način priznao svoje grijehe prema Karlu te molio od njega milost za sebe i svoje sinove. Tasilon, međutim, nije vraćen na položaj vojvode, već je ostao redovnikom, ali je zato stekao kraljevu milost i prijateljstvo. Kasnije je dedicij uključivao, kao svoj neizostavni dio i povratak na prethodno stanje, što se počelo redovito primjenjivati u sukobima između Ludovika Pobožnog i njegovih sinova, a zatim i u sukobima očeva i sinova u sljedećoj generaciji Karolinga. Dedicij, sada već u potpunosti prihvaćen kao mehanizam rješavanja sukoba, i, što je za tražitelja milosti bilo najvažnije, garancija povratka na status quo ante, svoj je vrhunac imao u 10. stoljeću u Istočnoj Franačkoj, dok se u Zapadnoj, kako je već spomenuto, koristio znatno rjeđe. Moguće je da je, pored drugih čimbenika, i nedostatak učinkovitog sredstva mirenja velikaše Zapadne Franačke postupno odvajao od svoga vladara i slabio integritet kraljevstva, dok su na Istoku vojvode nakon obavljenog podvrgnuća mogli biti bez većih problema vraćeni natrag u strukture moći. Postoje nebrojeni primjeri dedicija u ranosrednjovjekovnoj povijesti. ${ }^{50}$ Istaknuo bih možda i najpoznatiji u historiografiji koji je bio poseban po svojim sudionicima, onaj Henrika IV. u Canossi. Tijek događaja koji su se odvili na u zimu 1076./1077. detaljno je u svojim Analima opisao njemački kroničar

48 William Ian Miller, Bloodtaking and Peacemaking: Feud, Law and Society in Saga Iceland, Chicago 1990.; Geary, Vivre en conflict, str. 1107-1133; Petkov, Kiss of Peace, passim; Althoff, Spielregeln der Politik, str. 21-156.

49 Althoff, Spielregeln der Politik, str. 118.

50 Isto, str. 99-125; isti, Die Macht der Rituale, str. 32-130. 
Lambert iz Hersfelda. ${ }^{51}$ Pritisnut izopćenjem zbog kojeg mu je prijetio gubitak krune, Henrik je prešao Alpe i stigao do Canosse gdje se Papa sklonio na vijest o carevom dolasku. Ondje je Henrik, ničice, molio groficu Matildu za posredovanje kod Pape, što je ovjekovječeno na poznatoj ilustraciji u Vatikanskoj knjižnici. ${ }^{52}$ Iako je u historiografiji naviše upamćeno Henrikovo trodnevno bdijenje u pokajničkoj odjeći pred zidinama grada, Lampert otkriva da su tom simboličkom i upečatljivom činu prethodili dugotrajni pregovori tijekom kojih se Papa dugo opirao ali je, "nadvladan očajničkim ustrajanjem posrednika i težinom njihova argumenta", u konačnici pristao Henriku izdati upute kako može ponovno steći njegovu milost i osloboditi se izopćenja. ${ }^{53}$ Henrikov su slučaj pred Papom zagovarali njegova punica i šogor, zatim Matilda, markgrof Azon, opat Clunya i niz uglednih talijanskih kneževa za koje se znalo da "uživaju dobar ugled kod Pape". Prema tome, čitava scena, puna simboličkog značenja pokajanja i oprosta bila je detaljno razrađena iako je za javnost trebala djelovati potpuno spontano. Unatoč tome što je u pad ničice zamijenjen trodnevnim bdijenjem u pokajničkoj odjeći, ovaj se primjer dedicija svakako najviše usjekao u historijsku memoriju Europe. Pritom nije bilo nikakve sumnje da je Henrik učinio upravo dedicij, što su njegovi protivnici u Carstvu i naglašavali. ${ }^{54}$ Time je počelo i postupno propadanje samoga rituala jer je dedicij pred papom, u kojemu je car morao postupiti poput buntovnog vazala, ostavio gorak okus u ustima Henrika i njegovih nasljednika. Iako je i on sam prihvatio dedicij čitavog niza svojih pobunjenika, uključujući i veliku predaju Sasa svega nekoliko tjedana prije nego li je počeo sukob s Grgurom, nakon Canosse dedicij je u očima Nijemaca nepovratno povezan s osjećajem poniženja svjetovne pred crkvenom vlašću. U 14. je stoljeću, primjerice, slabijoj strani bilo nemoguće natjerati suparnika na određeni oblik ponašanja - oprost i povratak u hijerarhiju - putem ritualnih radnji jer je dedicij dotad već potpuno izgubio svoj učinak. ${ }^{55}$ Korijeni promjene nisu ležali samo u zbivanjima u Canossi, već su počeli znatno ranije, u vrijeme Henrika II.

\section{Henrik II. i utjecaj na Hrvatsku}

Za razliku od svojih prethodnika, car Henrik II. imao je vrlo precizno razrađen program propagande svoje vlasti i autoriteta. Pritom je pravo na vladavinu nad "kraljevstvom bez ikakvih podjela" (regnum sine aliqua divisione) izvodio manje preko svog podrijetla od sporedne grane otonske dinastije, a više kao izraz Božje volje i

51 Oswald Holder-Egger, Lamperti monachi Heresfelensis opera, Hannover 1894. (njemački prijevod: Ludwig Friedrich Hesse, Die Jahrbücher des Lambert von Hersfeld, Leipzig 1893.).

52 Bibliotheca Vaticana, Vita Mathildis, lat. 4922, fol. 49r.

53 Diu papa resistit, veritus in rege iuvenilis animi inconstantiam et proclive, quocumque assentatores impulissen, ingenium. Sed superatus tandem importunitate preurgentium et gravitate sententiarum. Holder-Egger, Lamperti monachi, str. 291.

54 Monika Suchan, Königsherrschaft im Streit: Konfliktaustragung in der regierungszeit Heinrichs IV. zwischen Gewalt, Gespräch und Schriftlichkeit, Stuttgart 1997., str. 74.

55 Gerald Schwedler, Herrschertreffen des Spätmittelalters: Formen - Rituale, Wirkungen, Ostfildern 2008., str. 230, 319. 
Providnosti čime je, s jedne strane htio naglasiti svoju integrativnu ulogu u Carstvu kako bi prevladao stare plemenske podjele i posebnosti, a s druge, pragmatičnije strane, otpor svojoj vlasti izjednačio je s pobunom protiv nebeskog poretka. Znakovito je da je, za razliku od svojih prethodnika, Henrik potpuno zanemario izbor kneževa te svoju vlast započeo izravno krunidbom, a bez prethodnog sabora velikaša. Jačanje kraljevske vlasti u vrijeme njegove vladavine toliko je uznapredovalo da mu je, primjerice, pošlo za rukom uvelike ograničiti vlast bavarskog i švapskog vojvode, te bez ikakvih konzultacija i konsenzusa proglasiti zemaljski mir u Saskoj i Švapskoj. Kompleksni vladarski program potkrijepio je obiljem pisane i slikovne ostavštine, a među kojima je, pored krunidbene freske u sakristiji u Regensburgu te Sakramentarija, njegov Evanđelistar iz Monte Cassina jedan od najljepših primjera. ${ }^{56}$ U vrijeme nijednog drugog vladara nije nastalo takvo obilje izvora koji izričito naglašavaju carevu ulogu kao čuvara, provoditelja i stvaratelja zakona i pravde. ${ }^{57}$

Henrik II. počeo je s uvođenjem inovacija i na polju rješavanja sukoba izmjenama u provedbi dedicija. Poput svojih prethodnika iz otonske dinastije, i on se mirio s pobunjenim velikašima, ali je, nedugo nakon učvršćenja na prijestolju povratak na status quo ante počeo uvjetovati kaznama. Prema Althoffu, milosrđe (clementia) je zamijenio pojmom pravde (justitia) i to tako što je svojim odmetnutim velikašima udjeljivao milost, ali uz utamničenje, ponekad i dugogodišnje..$^{58}$ Suvremenici su jasno primijetili promjene koje je car uveo te su ga neki, poput Bruna iz Querfuta, oštro kritizirali. ${ }^{59}$ Osloncem na ideju o osobi vladara kao vrhovnom zakonodavcu i arbitru - prema Fiskoviću rex iustus - prikaz na Evanđelistaru odgovarao bi dediciju, ali nadopunjenom i novouvedenim konceptom pravednosti. Henrikova vladarska propaganda bila je važan dio izgradnje njegove nove legitimacije moći uz oslonac na crkvu i kler te je bogat opus iz njegova vremena imao jasnu i planiranu svrhu: predstaviti vladara kao vrhovnog zaštitnika zakona i pravednosti na zemlji i kao neupitni autoritet postavljen Božjom providnošću. Evanđelistar pritom jasno ilustrira da se grešni podanici moraju predati na carevu milost (i nemilost), pa čak i ako nemaju tradicionalne garancije da će im oprost biti sigurno udijeljen. No, osnovni je simbolički izraz ostao gotovo nepromijenjen. Slabija strana je i dalje morala pasti ničice i nije nimalo iznenađujuće da je Henrik iz dedicija zadržao upravo taj element te ga i promicao kao poželjni obrazac ponašanja.

Istovremeno je upravo u vrijeme Henrika II. u izvorima zabilježeno podučavanje suparnika u provođenju dedicija. Poput Konrada I., koji je od budućeg cara Henrika I. izričito zahtijevao "spontani dedicij" kao preduvjet za njegovo prijateljstvo

56 Ilustracija naslovnice Evanđelistara nalazi se i na korici jedne od najvažnijih knjiga o teoriji dva kraljeva tijela i vlasti srednjovjekovnih kraljeva uopće: Ernst H. Kantorowicz, The King's Two Bodies: A Study in Medieval Political Theology, Princeton 1981.

57 Stefan Weinfurter, Authority and Legitimation of Royal Policy and Action, $\mathrm{u}$ : Medieval Concepts of the Past, ur. Gerd Althoff - Patrick Geary, Cambridge 2002., str. 19-38; Bernd Schneidmüller, Heinrich II. als zweiter Gründer der Alten Kapelle in Regensburg, u: Die Alte Kapelle in Regensburg, ur. Werner Schiedermair, Regensburg 2002., str. 45-67, 368-370.

58 Althoff, Die Macht der Rituale, str. 77-78.

59 Stefan Weinfurter, Authority and Legitimation, str. 19-38, ovdje, str. 31. 
i milost, Henrik II. je uprizorio dedicij pred poslanicima poljskog vojvode Boleslava Hrabrog kako bi ga poučio što mu je činiti prilikom susreta s carem želi li održati dobre odnose s Carstvom. ${ }^{60}$ Sličan "transfer znanja" zabilježen je i u vrijeme njegova nasljednika. Nakon pobjede nad Samuelom Abom, pretendentom na ugarsko prijestolje, Henrik III. je 1044. zajedno sa svojom vojskom bosonog pao ničice pred relikvijom svetog križa u znak zahvalnosti za pobjedu što je, zatim, ponovio i njegov saveznik, ugarski kralj Petar Orseolo u Stolnom Biogradu. Događaji koji su prethodili Henrikovoj intervenciji detaljno su opisani u kronici benediktinca Henrika iz Richenaua, jednog od najvažnijih svjedoka za povijest sredine jedanaestoga stoljeća. U kronici se navodi da je Petar Orseolo bio u carevoj nemilosti jer je dvije godine ranije podržao njegovog protivnika, češkog vojvodu Bretislava. Nakon Samuelove uzurpacije ugarskog prijestolja, Petar je bio prisiljen potražiti carevu pomoć, a kako bi je stekao morao ga je udobrovoljiti i zadobiti njegov oprost, što je ostvario padanjem ničice, odnosno dedicijem. ${ }^{61} \mathrm{Za}$ vrijeme sukoba između Kolomana i vojvode Almosa 1106., potonji se, nakon izbivanja iz kraljevstva, vratio uz pomoć poljskih odreda te je, nakon snažne vojne intervencije starijeg brata, "došao kralju pod noge te priznao svoju krivicu u svim stvarima" ${ }^{62}$ Obrasci javnog simboličkog djelovanja su se, što ovaj posljednji primjer zorno prikazuje, svjesno imitirali u državama koje su graničile s Carstvom i bili pod njegovim političkim i kulturnim utjecajem. ${ }^{63} \mathrm{~S}$ obzirom na propagandni program Henrika II., smatram da je slika na Evanđelistaru iz Monte Cassina prikazivala upravo dedicij uz novinu kralja pravednika koji oprašta, ali i kažnjava, što objašnjava i prisutnost na slici potencijalnog krvnika u uspravnom položaju pored tražitelja milosti s mačem u ruci. Prisutnost svjetovnog rituala mirenja u Evanđelistaru, ali i izgledna mogućnost da su benediktinci mogli prenijeti takav ikonografski motiv i na područje Dalmacije može se objasniti Henrikovim iznimno dobrim odnosom s Crkvom. U Njemačkoj su upravo biskupi bili oslonac njegove centralizirajuće politike. U toj mjeri je podržavao Crkvu donacijama i privilegijama da je s visokim klerom uspostavio odnos povjerenja kakav nije ostvario niti jedan njemački vladar prije ili poslije njega, te ga je kroničar Titmar Merseburški čak nazvao coepiscopus (subiskup). ${ }^{64}$ Stoljeće kasnije proglašen je i svecem. I sam čin da-

${ }^{60}$ Thietmari Merseburgensis episcopi Chronicon, prir. Friedrich Kurze, Monumenta Germaniae Historia. Scriptores rerum Germanicarum in usum scholarum separatim editi, sv. 54., Hanover 1889., str. 174; Althoff, Die Macht der Rituale, str. 72-73.

61 Ipso anno Ungarii perfidi Ovonem quendam regem sibi constituenses, Petrum regem suum occidere moliuntur. Qui vix fuga lapsus, primo ad marchionem nostrum Adalbertum, sororis suae maritum, profugus venit, indeque ad regem Heinricum veniens, pedibusque eius provolutus, veniam et gratiam improravit et impetravit (Herimani Augiensis Chronicon, prir. Georg Heinrich Perz, Monumenta Germaniae Historia. Scriptores, sv. 5, Hannover 1844., str. 124-125).

62 ... ad pedes regis venisset et in eo re omnium se culpabilem proclamavit (citirano prema: Dalewski, Ritual and Politics, str. 70).

63 Althoff, Die Macht der Rituale, str. 116.

${ }^{64}$ Posita est etiam in loco, qui Throtmunni dicitur, magna sinodus, ubi rex coepiscopus (Thietmari Merseburgensis, str. 143). Cf. Stefan Weinfurter, Heinrich II. (1002-1024). Herrscher am Ende der Zeiten. Regensburg 1999., str. 127, 145. 
rivanja Evanđelistara Monte Cassinu predstavljen je kao izraz njegove proklamirane religioznosti. ${ }^{65}$ Prema tradiciji, posjetio je samostan kako bi se uvjerio da u njemu zaista počivaju relikvije sv. Benedikta. Svetac je zatim izveo čudo kojim ga je poučio boljem načinu razmišljanja, dok je Henrik uzvratio obilnim darovima samostanu, uključujući i spomenuti Evanđelistar. ${ }^{66} \mathrm{~S}$ obzirom na njegov ugled u Crkvi, moguće je da su i benediktinci rado prihvatili i širili njegovu propagandu te je tako i prizor dedicija u Henrikovom shvaćanju isprepletenosti sacerdotiuma i regnuma našao svoje mjesto na reljefu hrvatskoga vladara.

Reljef hrvatskoga vladara u Splitu poseban je po tome što je stojećem dvorjaninu s kraljeve lijeve strane otučen predmet koji je držao u ruci. Raniji autori prepoznavali su u izbrisanome predmetu mač, dok se Fisković čvrsto založio za svitak ili rotulus. ${ }^{67}$ Iako se teško sa sigurnošću opredijeliti između dvije mogućnosti, i jedna i druga govore u prilog interpretaciji prizora kao scene sudovanja, odnosno mirenja i izricanja presude u skladu s promjenama koje je uveo Henrik II. Na Evanđelistaru je, ispod Henrika na prijestolju, prikazan upravo dvorjanin s mačem pored poniznog tražitelja milosti i oprosta. Ako je ipak riječ o svitku, sadržaj reljefa može se protumačiti kao trenutak izricanja presude. Oba moguća predmeta naglašavaju aspekt sudbene vlasti vladara. Položaj molitelja u prostraciji je zasigurno najsnažniji argument $u$ prilog prepoznavanja dedicija na reljefu budući da je pad ničice bio neizostavni preduvjet za vraćanje $\mathrm{u}$ vladarevu milost nakon sukoba. Iako je u Bizantu prostracija redovito korištena kao znak podčinjenosti pred carem, reljef u Splitu neupitno je nastao na zapadnim uzorima, o čemu svjedoče otonska kruna i prijestolje, kao i odjeća. Iz toga proizlazi da je i prostracija na reljefu došla sa Zapada, gdje se koristi kao dio dedicija.

Sačuvani izvori ne dopuštaju nam potvrditi je li i u kojoj mjeri dedicij u praksi bio korišten u srednjovjekovnoj Hrvatskoj. Simbolička komunikacija svakako jest jer je Hrvatska, poput ostalih rubnih država na obodu velikih Carstava, bila izložena prodiranju njihovih kulturnih i političkih utjecaja i obrazaca ponašanja. I Petar Krešimir i Zvonimir odluke su donosili u savjetu sa svojim velikašima, što je zabilježeno i u njihovim ispravama. ${ }^{68}$ Zvonimirova krunidba uključivala je i znakove kraljevske vlasti, insignije poput krune, žezla i zastave koje je kralju predao papin poslanik

65 Izraz proklamiran koristim budući da u njemačkoj historiografiji još uvijek postoje oprečna mišljenja o njegovoj religioznosti. Hartmut Hofman smatra ga iznimno religioznim, dok je Johannes Fried mišljenja da je bio vođen prvenstveno pragmatičnošću i željom za moći, a da je njegova religioznost u biti proizvod hladne proračunatosti. Svoje kristomimetično kraljevstvo stvorio je, prema Friedu, kako bi slomio otpor plemstva dok je u potpunosti zapostavio Rim, ali i visoku politiku svojih prethodnika koji su redovito razmjenjivali poslanstva s Bizantom. Usporedi Hartmut Hoffmann, Mönchskönig und "rex idiota". Studien zur Kirchenpolitik Heinrichs II. und Konrads II., Hannover 1993., str. 99; Johannes Fried, Der Weg in die Geschichte. Die Ursprünge Deutschlands bis 1024, Berlin 1998., str. 746.

66 Herbert Bloch, Monte Cassino in the Middle Ages, sv.1, Roma 1986., str. 19-20.

${ }^{67}$ Fisković, Reljef, str. 97-98.

68 Ego Cresmirus ... una cum nostris iupanis, comitibus atque banis, capellanis etiam nostre regalis aule, cogitare cepi... cum principibus ... ego Suinimir ... cum omnibus nobilibus meis (Codex diplomaticus Regni Croatiae, Slavoniae et Dalmatiae, prir. Ivan Kukuljević Sakcinski, Zagreb 1874., str. 131, 140, 161). 
Robert Kurelić: Ritual deditio na reljefu hrvatskoga vladara

Zb. Odsjeka povij. znan. Zavoda povij. druš. znan. Hrvat. akad. znan. umjet., 34 (2016), str. 1-20

Gebizon. ${ }^{69}$ Činjenica da je za datum krunidbe odabran dan sv. Demetrija (8. listopada) sugerira da je hrvatski kralj vješto baratao jezikom simboličke komunikacije. ${ }^{70}$ Ukoliko je točna pretpostavka da se reljef hrvatskoga vladara izvorno nalazio u krunidbenoj crkvu sv. Petra i Mojsija, moguće je i da je hrvatski vladar i svjesno emulirao propagandni imaginarij Henrika II. uz posredovanje benediktinaca. ${ }^{71}$ Nadalje, kako sam već spomenuo, u Ugarskoj je već u vrijeme Kolomana zabilježen ritual nalik dediciju, dok ga je kralj Petar Orseolo 1044. i osobno izvršio pred Henrikom III. Sv. Stjepan se 1001. sastao u Ostrogonu s Boleslavom Hrabrim kako bi se izmirili. Pritom su izmijenili poljubac mira, a zatim se zajednički, "ruku pod ruku" uputili na misu. Stjepan je, kao okrunjeni vladar nadređen vojvodi Boleslavu, iskoristio priliku da svoj viši položaj naglasi nošenjem krune kao simbola njegovog veličanstva, što je vrlo evokativno prenio i mađarski kroničar. ${ }^{72}$ I ugarski i hrvatski dvor koristili su neke od oblika simboličke komunikacije u javno-političkom životu. Veza između Zvonimira i Arpadovića mogla je samo dodatno pospješiti daljnje širenje obrazaca ponašanja etabliranih na Zapadu.

\section{Zaključak}

Iako hrvatski izvori ne bilježe izrijekom spomen na dedicij smatram da, zbog Henrikove vladarske propagande, njegovog dobrog odnosa s Crkvom, ali i općeg trenda prenošenja obrazaca simboličke komunikacije na zemlje u susjedstvu Svetog Rimskog Carstva, postoji velika vjerojatnost da je upravo taj značajni ritual mirenja ovjekovječen u prizoru na reljefu hrvatskoga vladara u Splitu. Prizor na reljefu prema svojim karakteristikama odgovara pravilima dedicija kakva su vrijedila u Carstvu u vrijeme Henrika II., a sličnost s njegovim Evanđelistarom koji se nalazio u posjedu benediktinaca upućuje na transmisiju ikonografije s Apeninskog poluotoka u Dalmaciju. Premda sam ritual možda i nije bio u redovitoj upotrebi u srednjovjekovnoj Hrvatskoj, jasno se nazire da je zabilježeni simbolički jezik hrvatskih kraljeva bio gotovo istovjetan onima na Zapadu. Reljef time dobiva na dodatnom značaju jer ne svjedoči samo o liku hrvatskoga vladara sa svojim insignijama i prijestoljem, već i o bliskoj povezanosti i isprepletenosti hrvatske srednjovjekovne države s tadašnjim kršćanskim Zapadom.

69 Tomislav Raukar, Hrvatsko srednjovjekovlje, Zagreb 1997., str. 49.

70 Zanimljivu teoriju o crkvi Sv. Petra i Mojsija iznio je Mladen Pejaković koji je ucrtao pentagram u tlocrt crkve te je izračunao da se desni krak pentagrama poklapa po smjeru zrake jutarnjeg sunca upravo na dan sv. Demetrija, što navodi na zaključak da je sama crkva građena s punim razumijevanjem i uporabom simbolike. Usp. Mladen Pejaković, Znakovi i značenja u hrvatskoj predromanici, u: Hrvatska i Europa: kultura, znanost i umjetnost, svezak 1: Srednji vijek (VII-XII. stoljeće). Rano doba hrvatske kulture, ur. Ivan Supičić, Zagreb 1997., str. 513-542; ovdje, str. 540.

71 Babić, O reljefu s prikazom kralja, str. 205.

72 "Kralj Stjepan, odjeven u svetu odoru i okrunjen kraljevskom krunom, svijetlio je poput sunca među zvijezdama, a hodajući iza procesije nadvisivao je obične ljude od ramena naviše" (Dušan Zupka, Power of Rituals and Rituals of Power. Religious and secular rituals in the political culture of medieval Kingdom of Hungary, u: History in Motion, ur. Roman Holec - Rastislav Kožiak, Bratislava 2010., str. 29-42). 


\section{Prilozi.}

Prilog 1. Evanđelistar Henrika II., c. 1020., fol. 193v. Vatikanska apostolska knjižnica

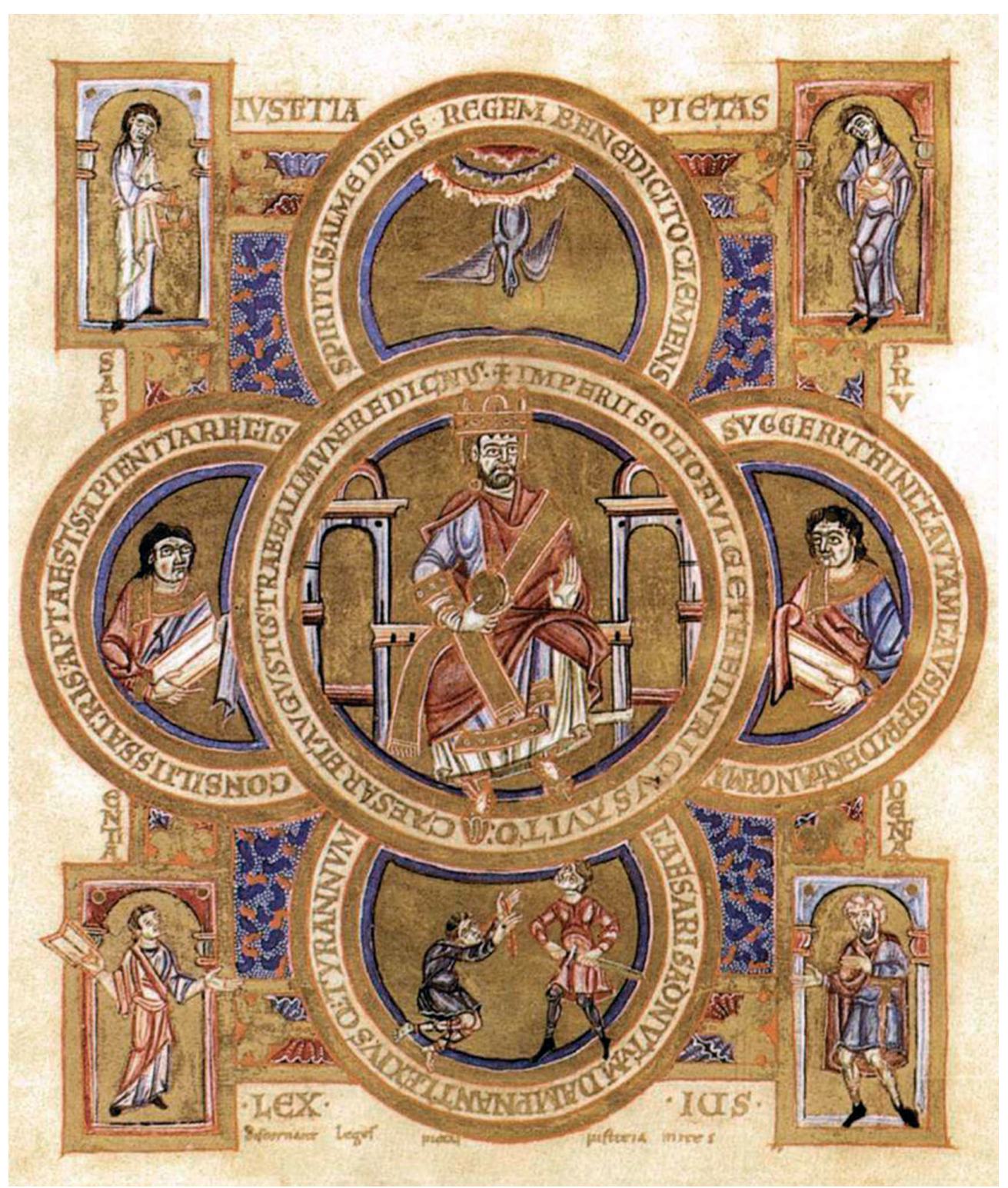


Robert Kurelić: Ritual deditio na reljefu hrvatskoga vladara

Zb. Odsjeka povij. znan. Zavoda povij. druš. znan. Hrvat. akad. znan. umjet., 34 (2016), str. 1-20

Prilog 2. Reljef hrvatskog vladara na istočnoj ploči krsnog bazena krstionice sv. Ivana u Splitu

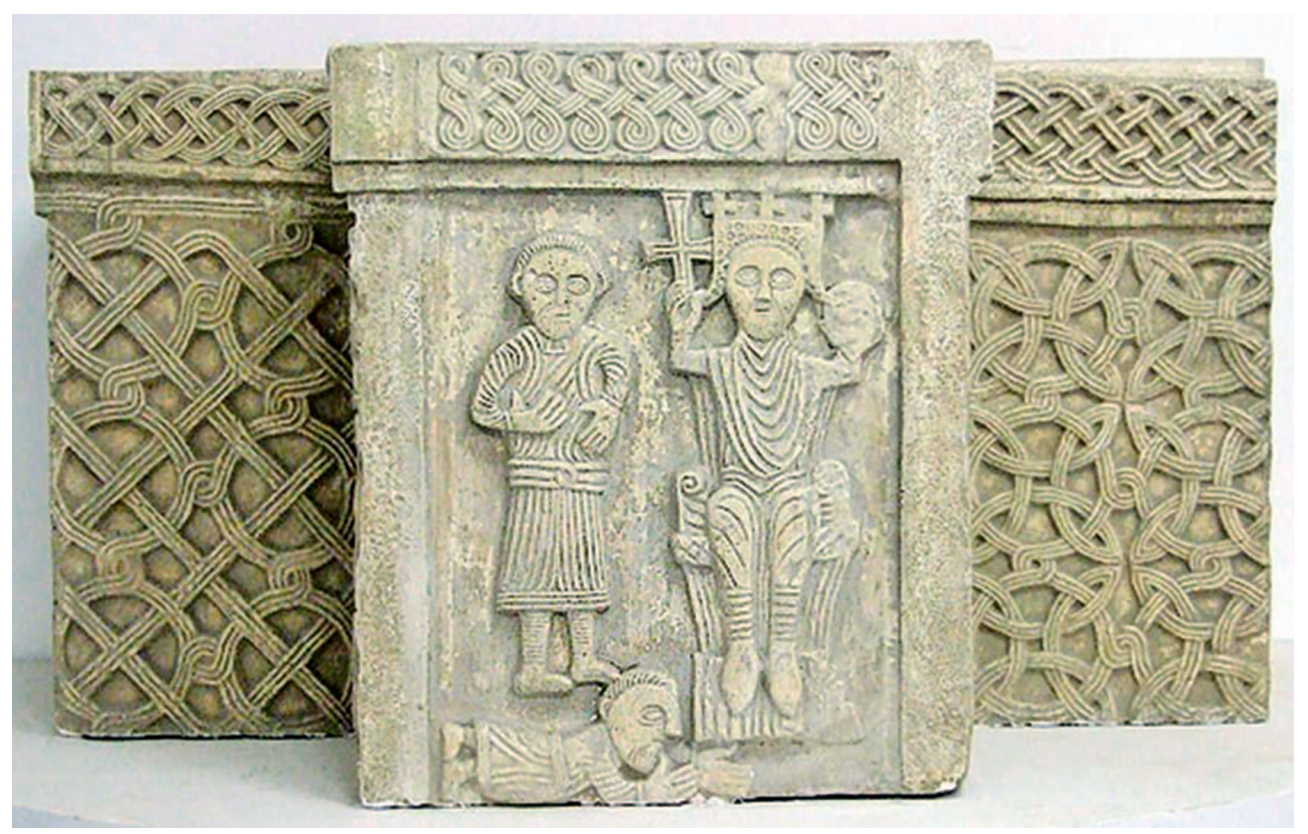


Robert Kurelić: Ritual deditio na reljefu hrvatskoga vladara

Zb. Odsjeka povij. znan. Zavoda povij. druš. znan. Hrvat. akad. znan. umjet., 34 (2016), str. 1-20

\title{
Robert Kurelić
}

\section{Ritual of the Deditio on the Relief Depicting a Croatian Ruler}

\author{
Summary
}

There are still a lot of unsolved questions regarding the relief depicting a Croatian ruler in the Baptistery of St. John the Baptist in Split. There is no consensus as to whether it depicts Christ or a ruler, and in the latter case, who the depicted ruler might be. The author accepts the hypothesis that this is a matter of one of two eleventh-century Croatian rulers, Peter Krešimir IV or Zvonimir, and proposes an explanation of the content of the relief as a depiction of the medieval ritual of submission, deditio, which served as means of re-obtaining the ruler's mercy and the return of rebellious vassals to his grace, and through that also their reestablishment within the hierarchy of power.

Rituals and symbolic communication played an important role in creating and maintaining the ruling hierarchy. By means of public, carefully planned and theatrically staged ceremonies, such as crowning, knighting or funerals, a sense of unity was demonstrated and traditional order was reaffirmed in the presence of the political public. In this respect, it is essential to stress the point that medieval power had an explicitly consensual character, and rulers carried out their will with the consent and support of their magnates, which demanded constant interaction.

The concept of feud, or Fehde, as an acceptable means of exercising rights and achieving satisfaction, allowed a vassal to engage in a military confrontation with his superiors, including the ruler himself. Any break in their interaction also meant the exclusion of the vassal from royal favour and political life, which posed a threat to the stability of the state. In order to renew symbolic harmony and achieve a return to royal favour, the ritual of the deditio was created; this was beneficial for the stability of the Empire, from the Frankish period up to Canossa. Henry II introduced innovations through which the deditio was connected with the ruler's judicial power, and in that way built it into the foundations of his ruling propaganda. It is probable that Henry II, through the agency of Monte Cassino, to which he donated his Gospel Book with a depiction of a deditio, influenced the transfer of iconographic form, which is then depicted on the aforementioned relief of the Croatian ruler.

Key words: symbolic communication, deditio, rituals of reconciliation, ruling propaganda, iconography, Peter Krešimir IV, Demetrius Zvonimir 